\title{
Effect of Nitrogen on Yield and Oil Quality of Sunflower (Helianthus annuus L.) Hybrids under Sub Humid Conditions of Pakistan
}

\author{
Wajid Nasim ${ }^{1,2,3,4^{*}}$, Ashfaq Ahmad ${ }^{2}$, Asghari Bano ${ }^{1}$, Rabiu Olatinwo ${ }^{3}$, Muhammad Usman ${ }^{5}$, \\ Tasneem Khaliq ${ }^{2}$, Aftab Wajid ${ }^{2}$, Hafiz Mohkum Hammad ${ }^{2,6}$, Muhammad Mubeen ${ }^{2}$, Muzzammil Hussain ${ }^{7}$ \\ ${ }^{1}$ Department of Plant Sciences, Quaid-i-Azam University, Islamabad, Pakistan; ${ }^{2}$ Agro-Climatology Laboratory, Department of \\ Agronomy, University of Agriculture, Faisalabad, Pakistan; ${ }^{3}$ Department of Biological \& Agricultural Engineering, University of \\ Georgia, Griffin, USA; ${ }^{4}$ Department of Environmental Sciences, COMSATS Institute of Information Technology (CIIT-Vehari \\ Campus), Vehari, Pakistan; ${ }^{5}$ Department of Irrigation \& Drainage, University of Agriculture, Faisalabad, Pakistan; ${ }^{6}$ AgWeatherNet, \\ Washington State University, Prosser, USA; ${ }^{7}$ Adaptive Research Farm Gujranwala, Government of Punjab, Lahore, Pakistan. \\ Email: *wajidnaseem2001@gmail.com, wajidnasim@ciitvehari.edu.pk
}

Received December $7^{\text {th }}, 2011$; revised December $28^{\text {th }}$, 2011; accepted January $15^{\text {th }}, 2012$

\begin{abstract}
Sunflower (Helianthus annuus L.) has emerged as an economically important crop in Pakistan due to its significant share in vegetable oil production. The plant metabolic processes require protein to increase the vegetative, reproductive growth and yield of the crop. The protein is wholly dependent upon the amount of nitrogen fertilization available for plant use. A two-year field study was conducted in 2008 and 2009. The objective was to determine the effect of different nitrogen (N) levels $\left(\mathrm{N}_{1}=0 \mathrm{~kg} \cdot \mathrm{ha}^{-1}, \mathrm{~N}_{2}=60 \mathrm{~kg} \cdot \mathrm{ha}^{-1}, \mathrm{~N}_{3}=120 \mathrm{~kg} \cdot \mathrm{ha}^{-1}, \mathrm{~N}_{4}=180 \mathrm{~kg} \cdot \mathrm{ha}^{-1}\right.$ and $\left.\mathrm{N}_{5}=240 \mathrm{~kg} \cdot \mathrm{ha} \mathrm{C}^{-1}\right)$ on three sunflower hybrids (Hysun-33, Hysun-38 and Poineer-64A93) in agro-climatic conditions of Gujranwala, a sub-humid region in the centre of the Punjab province of Pakistan. A randomized complete block design split plot experiment was set-up with cultivars in the main plots and $\mathrm{N}$ levels in the subplots. Results showed that Hysun-38 gave maximum TDM (15815 kg $\left.\cdot \mathrm{ha}^{-1}\right)$ and maximum grain yield (3389 kg $\left.\cdot \mathrm{ha}^{-1}\right)$, while minimum TDM $\left(14640 \mathrm{~kg} \cdot \mathrm{ha}^{-1}\right)$ and grain yield $\left(3125 \mathrm{~kg} \cdot \mathrm{ha}^{-1}\right.$ ) was observed in Hysun-33. Among different $\mathrm{N}$ rates evaluated, $\mathrm{N}_{4}$ gave maximum TDM $\left(17890 \mathrm{~kg} \cdot \mathrm{ha}^{-1}\right)$ and grain yield $\left(3809 \mathrm{~kg} \cdot \mathrm{ha}^{-1}\right)$ compared to the other $\mathrm{N}$ rates. The maximum oil content $(46.2 \%)$ was observed in Hysun-38 without application of $\mathrm{N}$ fertilizer $\left(\mathrm{N}_{1}\right)$, while the minimum oil content $(40.6 \%)$ was observed from $\mathrm{N}_{5}$ treatment. In conclusion, the application of $180 \mathrm{~kg} \cdot \mathrm{ha}^{-1} \mathrm{~N}$ to Hysun-38 provided the best combination for good yield in sunflower crop under the prevailing sub-humid conditions of Pakistan.
\end{abstract}

Keywords: Helianthus annuus L.; Nitrogen Rates; Yield; Subhumid Conditions; Pakistan

\section{Introduction}

Sunflower (Helianthus annuus L.) is one of the most important oilseed that originally belonged to subtropical and temperate zones [1,2] crop and it is widely adaptable and more drought tolerant than most other grain crops [3]. It is well adjusted to soil that has high water-holding capacity but is easily adapted to a range of soil conditions [4]. Nutrients play an important role in crop growth and development. Among the nutrients, $\mathrm{N}$ is one of the major nutrients that enhance the metabolic processes that based on protein, leads to increases in vegetative, reproductive growth and yield of the crop $[5,6]$. As the history indicates that there is a severe shortage of edible oilseeds in Pakistan that can hardly accumulate the requirements. To

"Corresponding author. meet the needs of population and never-ending rise in urbanization has led to broaden the gap between local availability and requirement to increase in number of mouths as well as rise in per capita consumption. So, total domestic fling of edible oil stood at about 3.07 million tons, of which $27.20 \%$ ( 0.83 million tons) came from local production (GOP, 2009). Thus, the country is constrained to import edible oil in large quantities. The import of edible oil accounts largest drain on national exchequer that is second to only mineral oil. The import bill is imposing a severe drain on foreign exchange reserves. During 2008-2009 (July-March), Pakistan spent Rs. 84000 million for 1290 thousand tons of edible oil and Rs.13756.83 million for 723.96 thousand tons of oilseeds during 2008-2009. A developing country like ours cannot afford such a mounting export bill indeed. The situation 
thus warrants enhancing the indigenous oilseed production to set aside the country from a foremost disaster in not too far a future. The local production of edible oil in Pakistan stood at 6.84 million tons during 2008-2009, which is almost $24 \%$ of the total local demand, while the remaining $76 \%$ is imported with estimated cost of Rs. 80 billion annually [7]. In Pakistan, sunflower was sown on approximately $3.53 \mathrm{M}$ ha with total production of $5.54 \mathrm{M}$ tons for seed and $2.11 \mathrm{M}$ tons for oil, respectively [7]. The research and development constraints limiting increased production include non-availability of suitable local hybrids/cultivars, high cost of imported seed and losses due to bird damage near the crop maturity. Others include defective and inefficient marketing system, unavailability and high prices of inputs, reliance on old traditional methods of sowing and harvesting, post harvest problems and the lack of awareness of the farmers about latest sunflower production technology [8]. The present study, therefore, was conducted with the objective to evaluate the effect of different $\mathrm{N}$ rates on achene's oil quality, yield and yield components of different sunflower hybrids under Gujranwala's agro-climatic conditions of Punjab, Pakistan.

\section{Materials and Methods}

The experiment was conducted on the Adaptive Research Farm, Gujranwala (32 $\left.19 " \mathrm{~N}, 74^{\circ} 17^{\prime \prime} \mathrm{E}\right)$, which represents the sub-humid agro-ecological region in Pakistan (Figures 1 and 2). Gujranwala has a shallow, fine, silty, mixed and hyperthermic soil. Its color is medium brown,

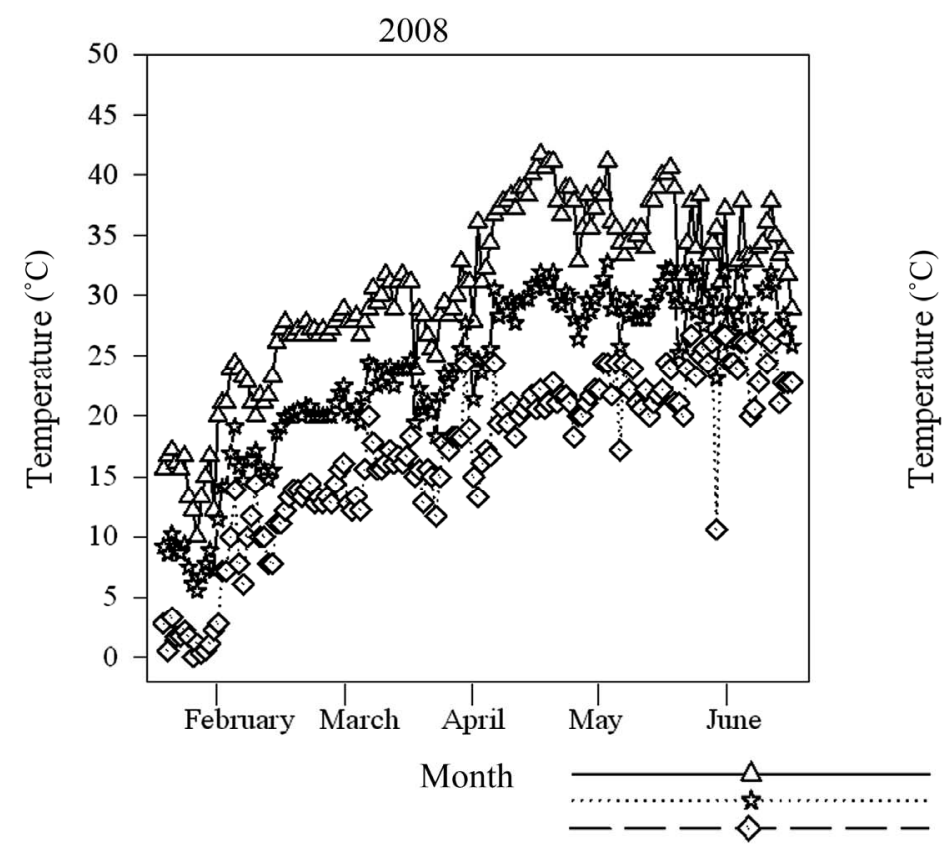

moderately well drained, with field capacity (FC) of 0.57 $\mathrm{m}^{3} \mathrm{~m}^{-3}$ and permanent wilting point of $0.23 \mathrm{~m}^{3} \mathrm{~m}^{-3}$ having the $\mathrm{pH}$ ranges from $8.1-8.6$, while the organic matter percentage was $0.87 \%$ in the whole profile [4]. In this study, there were fifteen treatments, including five $\mathrm{N}$ levels $\left(\mathrm{N}_{1}=0 \mathrm{~kg} \cdot \mathrm{ha}^{-1}, \mathrm{~N}_{2}=60 \mathrm{~kg} \cdot \mathrm{ha}^{-1}, \mathrm{~N}_{3}=120 \mathrm{~kg} \cdot \mathrm{ha}^{-1}\right.$, $\mathrm{N}_{4}=180 \mathrm{~kg} \cdot \mathrm{ha}^{-1}$ and $\mathrm{N}_{5}=240 \mathrm{~kg} \cdot \mathrm{ha}^{-1}$ ) and three sunflower hybrids (Hysun-33, Hysun-38 and Poineer-64A93). Phosphorus ( $\mathrm{P}$ ) and Potassium $(\mathrm{K})$ were used at the rate of $60 \mathrm{~kg} \cdot \mathrm{ha}^{-1}$ each, in all plots. N, P, and K, were applied in the form of urea, triple super phosphate and sulphate of potash $\left(\mathrm{K}_{2} \mathrm{SO}_{4}\right)$, respectively. A 1/3rd dose of $\mathrm{N}$ and all of the $\mathrm{P}$ and $\mathrm{K}$ fertilizer were applied at the time of sowing, while remaining 2/3rd of $\mathrm{N}$ was used in two splits; first dose at first irrigation and second dose of $\mathrm{N}$ at the flowering stage of crop during both years. Crop was irrigated as the crop required irrigations without any water stress. The experimental field was well-prepared to form ridges (70 cm spaced), the experiment was laid out in randomized complete block design with split plot arrangement having three replications. The crop was sown in February 2008 and 2009 with hand-mounted seed drill (dibbling) placing three seeds per hill, keeping in between plant distance at $20 \mathrm{~cm}$, using a recommended seed rate of $7 \mathrm{~kg} \cdot \mathrm{ha}^{-1}$. The net plot size was $4.2 \mathrm{~m} \times 5 \mathrm{~m}$. Sunflower hybrids were kept in main plots while different $\mathrm{N}$ levels were applied to the sub-plots. After crop establishment, near 2 - 4 leaf stage, seedlings were thinned down to one per hill manually, to keep optimum plant population. During the 2008 and 2009 growing seasons,

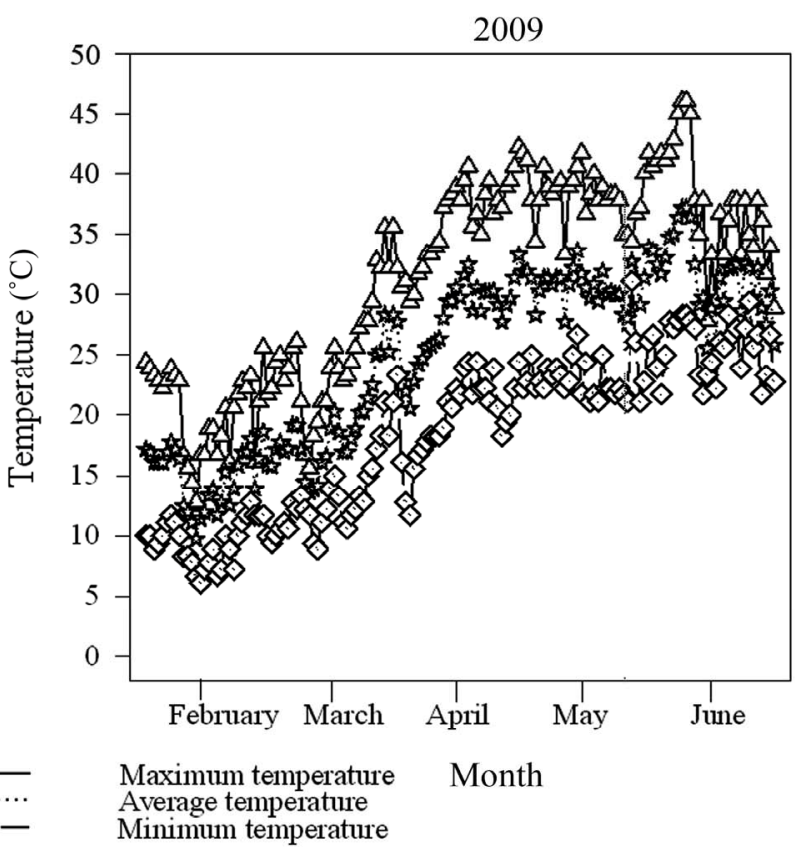

Figure 1. The daily temperature (maximum, minimum and average) during the 2008-2009 sunflower growing seasons in the sub-humid area of Pakistan. 


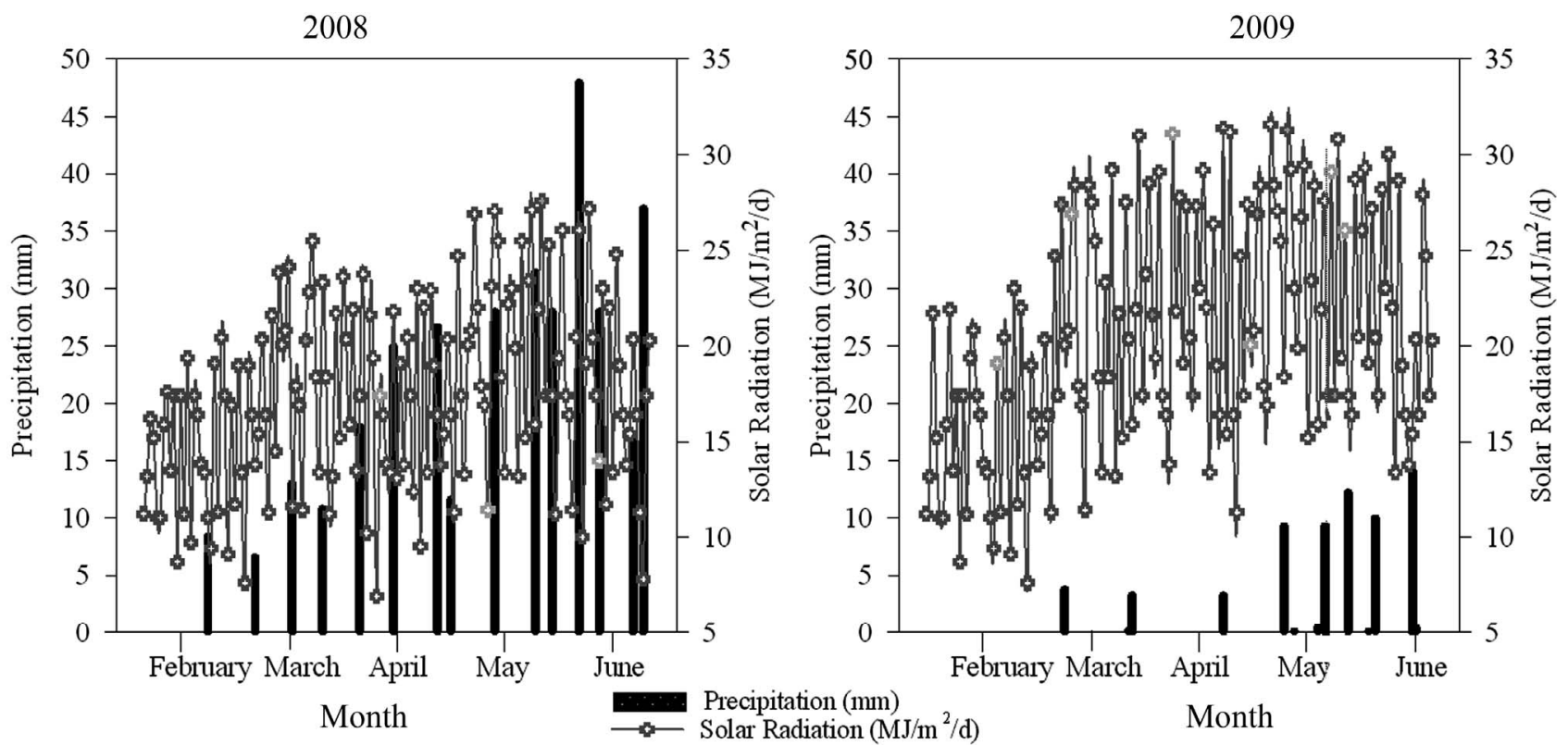

Figure 2. Precipitation and solar radiation during the 2008-2009 sunflower growing seasons in the sub-humid area of Pakistan.

two manual weeding by hoe were done to control weeds, the crop was then earthed up to protect it from lodging. All the cultural practices (hoeing, weed management, irrigation, plant protection measures etc.) were kept normal for the crop. The cropping husbandry and oil determination method were determined [9]. The data on leaf area index, total dry matter, head diameter, number of grains, 1000-grain weight, grain yield, and harvest index and achene oil content were taken. Data collected from the experiments were statistically analyzed using the computer statistical program MSTAT-C [10]. Mean comparison among treatments were evaluated using the least significance difference (LSD) test at $\mathrm{P}=0.05$ for yield and yield components of the sunflower crop.

\section{Results and Discussion}

\subsection{Weather Conditions}

There were differences in environmental conditions during both years; spring season 2008 was cooler while spring season 2009 was hotter. All the weather data (minimum and maximum temperature, relative humidity, rainfall, solar radiation) were obtained from the nearest meteorological observatory around the experimental site. Figures $\mathbf{1}$ and $\mathbf{2}$ indicate the means of weather elements during 2008 and 2009. Gujranwala was considered as cooler with minimum temperature and maximum rainfall especially during experimental year 2008. Rainfall was experienced more during spring 2008 than spring 2009 growing seasons. Gujranwala had precipitation of 263 $\mathrm{mm}$ in 2008 and $106.7 \mathrm{~mm}$ in 2009. Solar radiation was observed 22.3 MJ $\cdot \mathrm{m}^{-2} \cdot \mathrm{d}^{-1}$ during 2008 and almost similar trend was observed in year 2009 (Figure 2).

\subsection{Leaf Area Index}

Leaf area index (LAI) progressively increased and achieved its maximum value at 60 days after sowing (DAS); thereafter; LAI decreased in all the treatments and reached its lowest value at less than 0.5 by 105 DAS during 2008 and 2009 seasons, respectively (Figure 3). Such reduction in LAI was more pronounced in lower $\mathrm{N}$ levels $\left(0\right.$ and $\left.60 \mathrm{~kg} \cdot \mathrm{N} \cdot \mathrm{ha}^{-1}\right)$ than high $\mathrm{N}$ levels due to early senescence of leaves, earlier than the latter stages of growth of sunflower crop. Maximum LAI value was observed in hybrids Hysun-38 followed by Pioneer-64A93 and the minimum LAI was observed in Hysun-33 during 2008 and almost similar trend of treatments was observed in year 2009 but on an average basis year 2008 produced more LAI compared to 2009 (Figure 3). Furthermore, maximum LAI reached to a value at 65 DAS in $\mathrm{N}_{4}$ and minimum value for LAI was recorded in $\mathrm{N}_{1}$ (Figure 4). The greater leaf expansion shown in sunflower hybrids could be attributed to higher rate of cell division and cell enlargement [11-13].

\subsection{Total Dry Matter}

The total dry matter (TDM) production increased progressively, after crop establishment and continued until maturity in all the treatments. Maximum TDM was observed to be higher in 2008 than in 2009 growing season for the three hybrids, which could be due to more favorable 


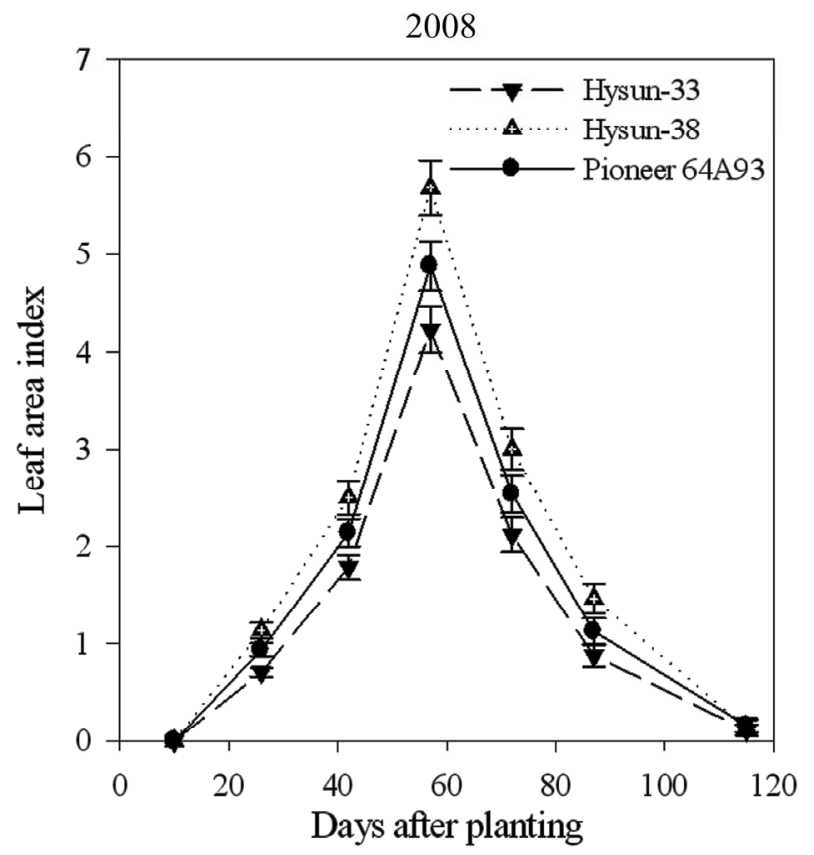

(a)

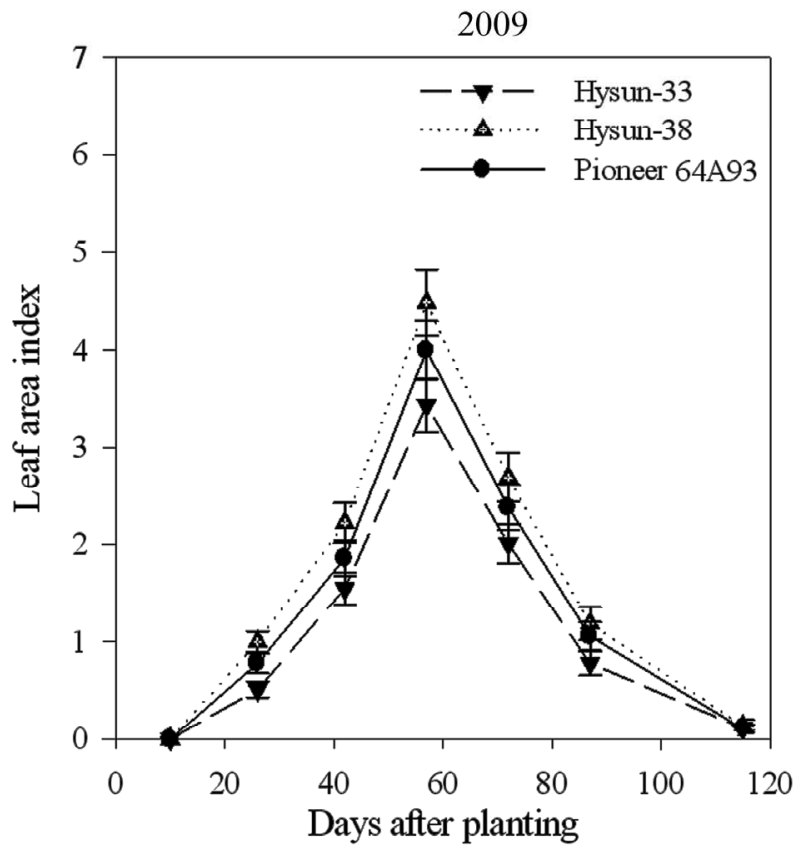

(b)

Figure 3. The Leaf Area Index (LAI) and the standard error of the mean for three hybrids during the 2008 (a) and 2009 (b) crop cycle under subhumid conditions of Pakistan.

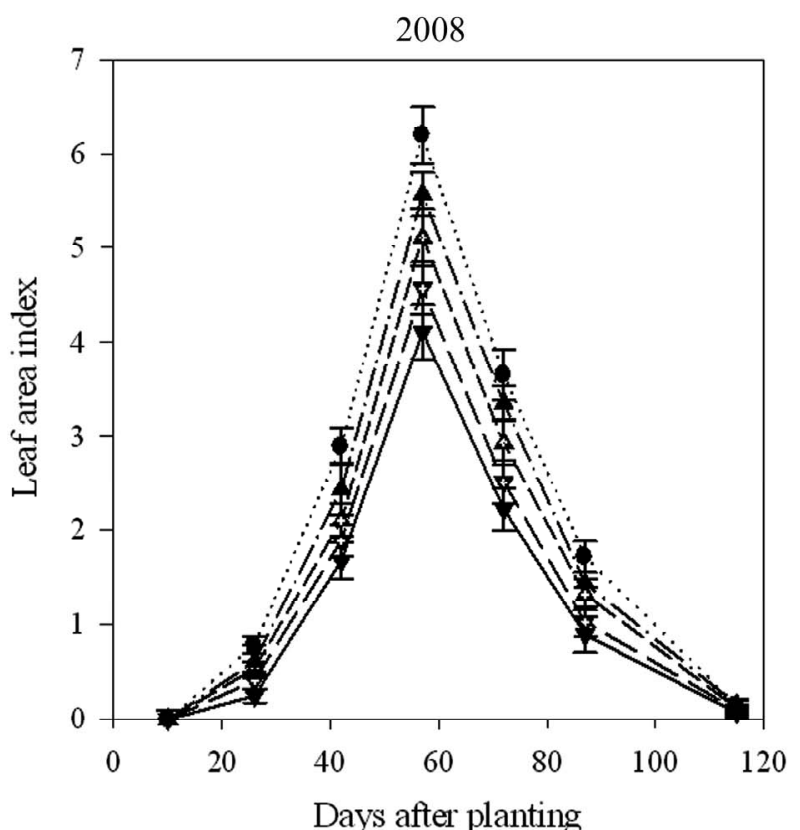

Days after planting

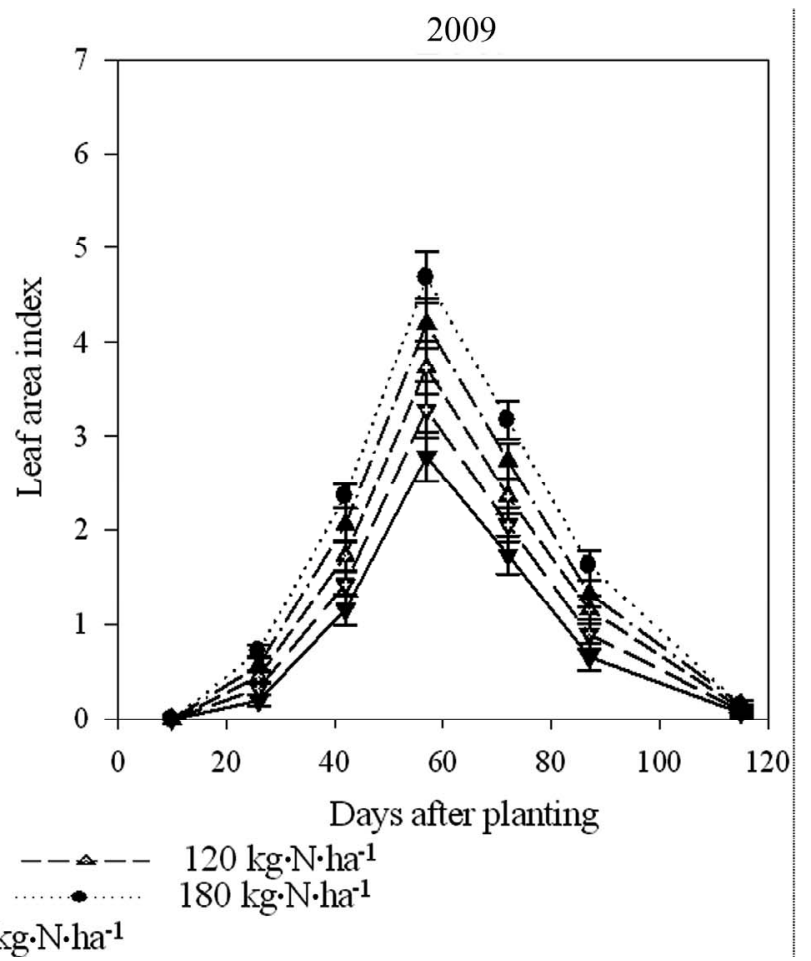

(b)

Figure 4. The Leaf Area Index (LAI) and the standard error of the mean for different nitrogen levels during the 2008 (a) and 2009 (b) crop cycle under subhumid conditions of Pakistan.

conditions (more rainfall with low temperature in spring 2008) during 2008 than in 2009 (Figure 2). A maximum
TDM was observed in hybrids Hysun-38 followed by Pioneer-64A93, and the minimum TDM was observed in 
Hysun-33, both during 2008 and 2009 seasons (Figure 5). Maximum TDM was reported in $\mathrm{N}_{4}$ treatments followed by $\mathrm{N}_{5}$ while minimum value of final TDM was observed in $\mathrm{N}_{1}$ (Figure 6). The enhancement in TDM with increasing rate of nitrogen was due to better crop growth rate, which gave maximum photosynthates ultimately producing higher biological yield. The study also corroborates previous work done [14-16] on the use of different $\mathrm{N}$ levels.

\subsection{Head Diameter}

The results in Table 1 showed significant differences in head diameter during 2008 and 2009. The pooled mean from 2008 and 2009 indicate that, Hysun-38 had the higher head diameter $(19.4 \mathrm{~cm})$ followed by Pioneer64A93 $(18.7 \mathrm{~cm})$, while statistically lower head diameter $(17.7 \mathrm{~cm})$ was observed in Hysun-33. The response of $\mathrm{N}$ fertilizer with various rates on head diameter was higher with increasing trend of $\mathrm{N}$ fertilizer. The maximum head diameter $(21.2 \mathrm{~cm})$ was produced by $\mathrm{N}_{4}$ treatment followed by $\mathrm{N}_{5}$ that produced $20.4 \mathrm{~cm}$ head diameter and statistically minimum head diameter $(15.3 \mathrm{~cm})$ was recorded in plot that was not fertilized with $\mathrm{N}\left(\mathrm{N}_{1}\right)$. These results validate the findings $[17,18]$ that have also the evidence regarding to positive effects of nitrogen on head diameter.

\subsection{Number of Grains}

Hysun-38 showed significantly high values of grains per head (1051), followed by Pioneer-64A93 (1041) and

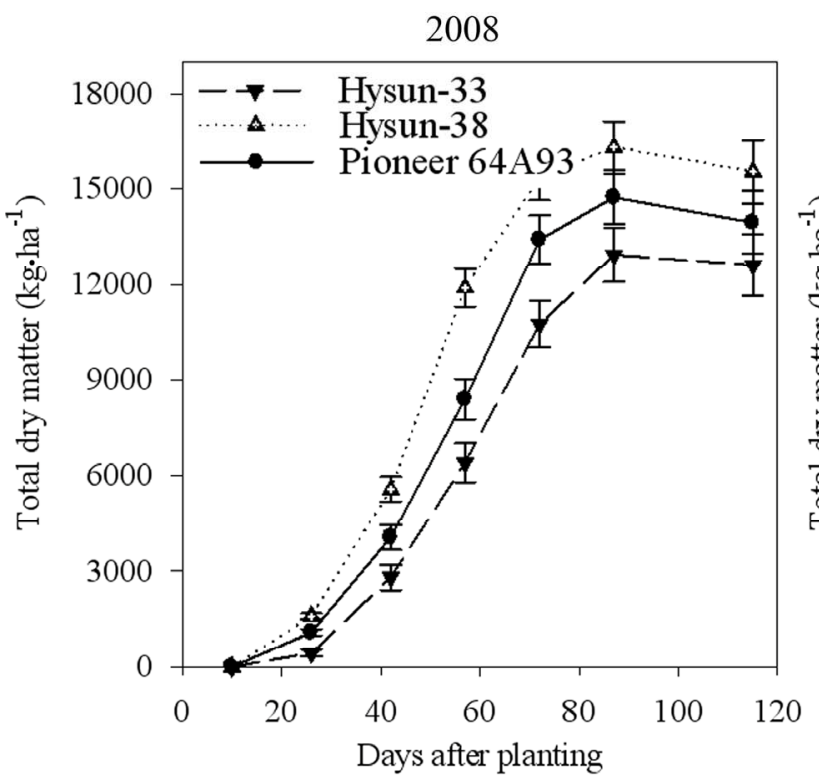

(a) statistically minimum values of grains per head were observed by Hysun-33 (1008), respectively (Table 1). While in case of $\mathrm{N}$ treatments, $\mathrm{N}_{4}$ produced statistically higher grains per head (1215), followed by $\mathrm{N}_{5}$ (1163), while statistically, $\mathrm{N}_{1}$ gave minimum grains per head (807). These results corroborate the studies $[19,20]$ who also reported that the shortage of $\mathrm{N}$ affects the development and growth of source and sink, as well as the number of achene per head and also some scientists also explain the similar characteristics of the sunflower hybrids used in this study [20].

\subsection{Thousand Grain Weight}

The average grain weight is critical yield contributing factor, which take up an important role in representing the potential of respective hybrid. Maximum grain weight were observed in Hysun-38 (48.3 g) followed by Pioneer-64A93 (47.3 g) and minimum grain weight was observed (46.6 g) in Hysun-33. In the similar way, among different $\mathrm{N}$ levels, Maximum 1000 grain weight (56.9 g) was produced in $\mathrm{N}_{4}$ treatment, followed by $\mathrm{N}_{5}(53.7 \mathrm{~g})$ treatment. The minimum 1000 grain weight (35.5 g) was obtained by the treatment without application of nitrogen fertilizer (Table 1). An increase in grain weight of sunflower hybrids in response to $\mathrm{N}$ fertilization has also been reported [21,22].

\subsection{Grain Yield}

The constructive climatic conditions (lower temperature and higher relative humidity) during growing season

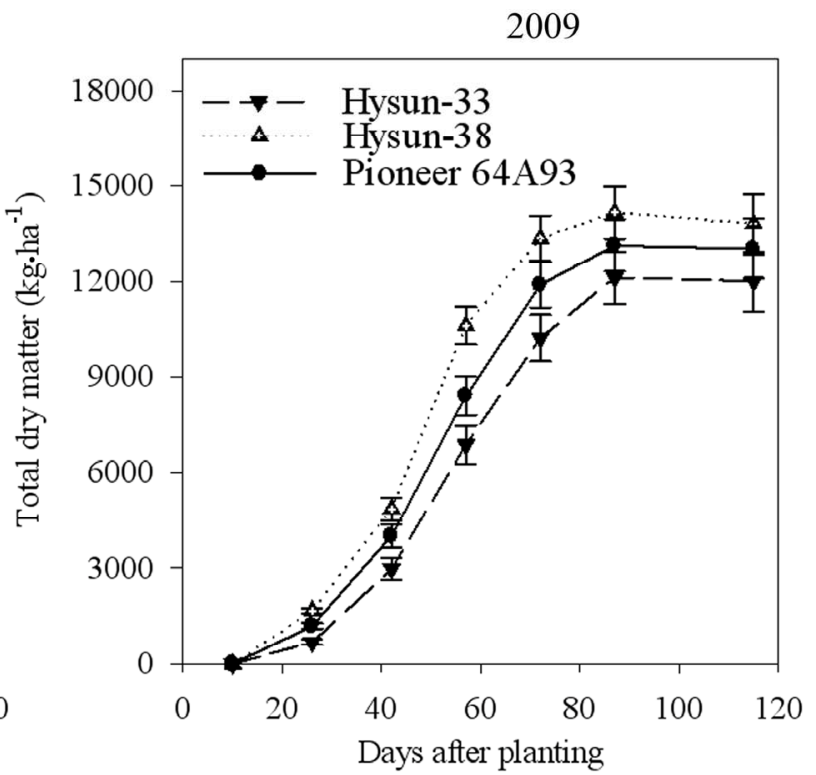

(b)

Figure 5. The Total Dry Matter (TDM) and the standard error of the mean for three hybrids during the 2008 (a) and 2009 (b) crop cycle under subhumid conditions of Pakistan. 


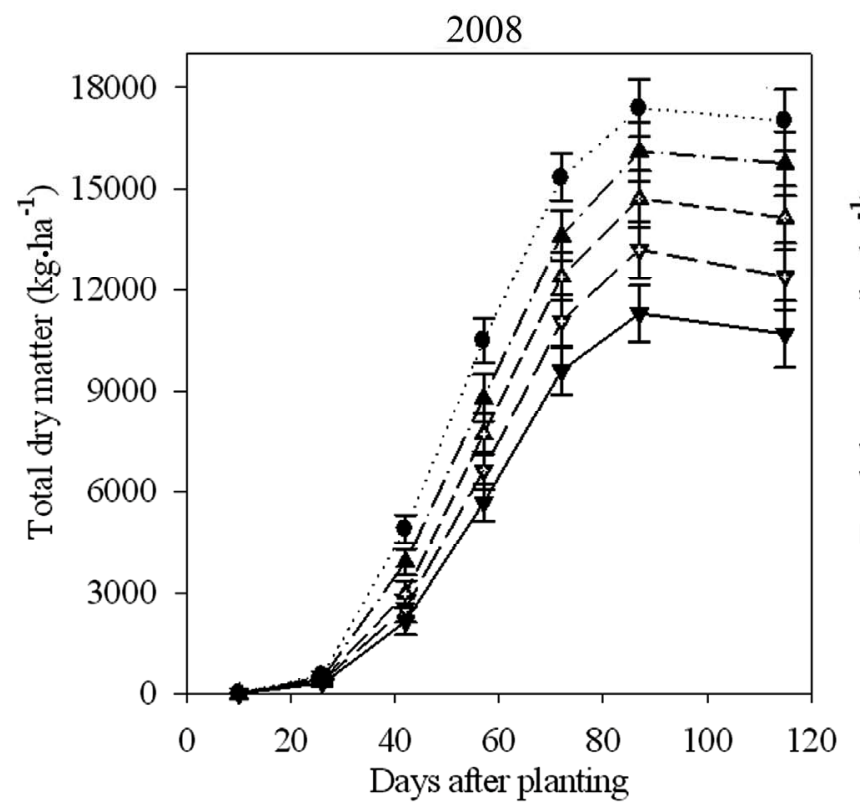

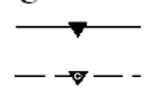

$$
\begin{aligned}
& 0 \mathrm{~kg} \cdot \mathrm{N} \cdot h \mathrm{~h}^{-1} \quad--\triangle-- \\
& 60 \mathrm{~kg} \cdot \mathrm{N} \cdot h \mathrm{a}^{-1} \\
& \text { _._. } 240 \mathrm{~kg} \cdot \mathrm{N} \cdot \mathrm{ha}^{-1}
\end{aligned}
$$

(a)

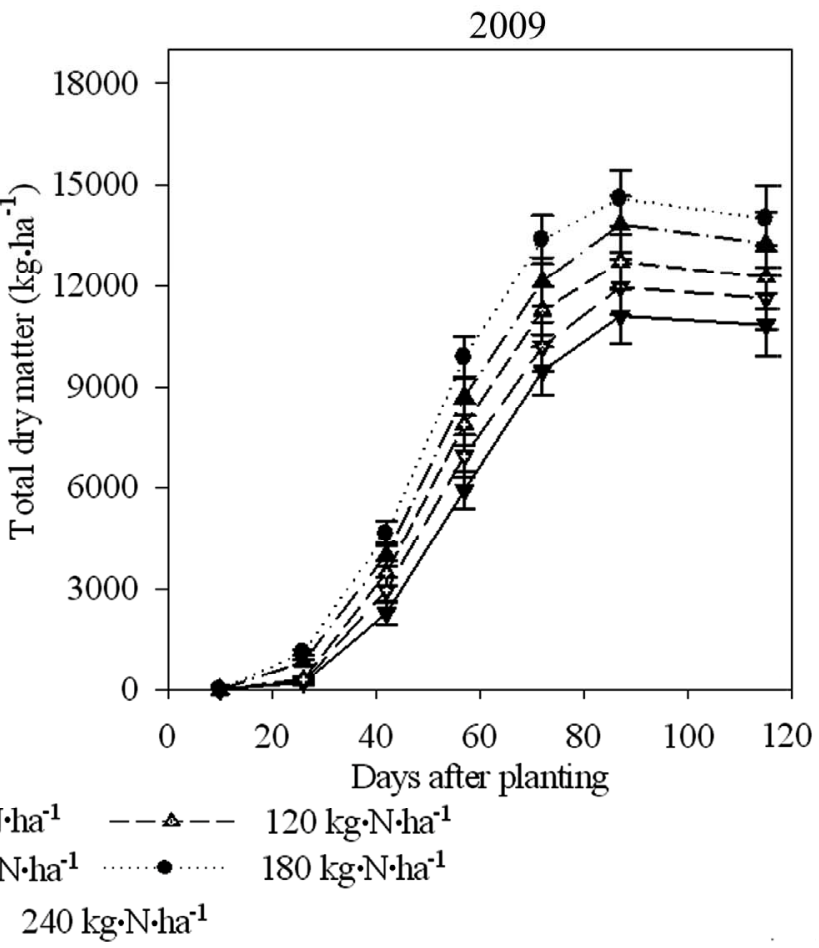

(b)

Figure 6. The Total Dry Matter (TDM) and the standard error of the mean for different nitrogen levels during the 2008 (a) and 2009 (b) crop cycle under subhumid conditions of Pakistan.

\begin{tabular}{|c|c|c|c|c|c|c|c|c|c|}
\hline \multirow{2}{*}{ Treatments } & \multicolumn{3}{|c|}{ Head diameter $(\mathrm{cm})$} & \multicolumn{3}{|c|}{ Number of grains $\left(\right.$ head $^{-1}$ ) } & \multicolumn{3}{|c|}{1000 grain weight (g) } \\
\hline & 2008 & 2009 & Pooled mean & 2008 & 2009 & Pooled mean & 2008 & 2009 & Pooled mean \\
\hline Hysun-33 & $18.4 \mathrm{~b}$ & $17.1 \mathrm{~b}$ & $17.7 \mathrm{c}$ & $1079 b$ & 938c & $1008 b$ & $48.1 b$ & $45.2 \mathrm{c}$ & $46.6 \mathrm{c}$ \\
\hline Pioneer-64A93 & $18.9 b$ & $18.5 \mathrm{a}$ & $18.7 \mathrm{~b}$ & $1084 c$ & $998 b$ & $1041 \mathrm{a}$ & $48.2 b$ & $46.4 \mathrm{~b}$ & $47.3 \mathrm{~b}$ \\
\hline LSD (0.05) & 0.67 & 0.87 & 0.66 & 12.41 & 14.10 & 12.60 & 0.15 & 0.36 & 0.23 \\
\hline \multicolumn{10}{|l|}{ Nitrogen $\left(\mathrm{kg} \cdot \mathrm{ha}^{-1}\right)$} \\
\hline 0 & $15.4 \mathrm{e}$ & $15.2 \mathrm{c}$ & $15.3 d$ & $867 e$ & $746 \mathrm{e}$ & 807e & $37.4 \mathrm{e}$ & 33.6e & $35.5 \mathrm{e}$ \\
\hline 60 & $17.8 \mathrm{~d}$ & $16.6 \mathrm{c}$ & $17.2 \mathrm{c}$ & $1001 d$ & 904d & $952 d$ & $41.3 d$ & 39.9d & $40.6 \mathrm{~d}$ \\
\hline 120 & $19.3 c$ & $18.2 b$ & $18.8 b$ & $1151 c$ & $1012 c$ & $1081 c$ & $51.5 c$ & $49.2 c$ & $50.3 c$ \\
\hline 180 & $22.2 \mathrm{a}$ & $20.3 a$ & $21.2 \mathrm{a}$ & $1261 \mathrm{a}$ & $1169 a$ & $1215 a$ & $57.4 \mathrm{a}$ & $56.5 a$ & $56.9 a$ \\
\hline 240 & $20.8 b$ & 19.9a & $20.4 a$ & $1218 b$ & $1109 b$ & $1163 b$ & $55.3 b$ & $52.2 b$ & $53.7 b$ \\
\hline LSD (0.05) & 1.18 & 1.44 & 1.29 & 14.30 & 13.10 & 12.20 & 0.99 & 0.92 & 0.94 \\
\hline Interaction $(\mathrm{H} \times \mathrm{N})$ & NS & NS & NS & NS & NS & NS & NS & NS & NS \\
\hline
\end{tabular}

Table 1. Effect of different nitrogen rates on the yield components of sunflower hybrids under agro-climatic conditions Gujranwala-Pakistan.

Figures in the same column with different letters differ significantly at probability level of ${ }^{*} \mathrm{P}=5 \%{ }^{* *} \mathrm{P}=1 \%$, NS—non-significant.

especially at grain filling stage might be the reason of higher grain yield especially, during 2008 than 2009. Higher grain yield was recorded from hybrid Hysun-38 $\left(3389 \mathrm{~kg} \cdot \mathrm{ha}^{-1}\right)$ followed by Pioneer-64A93 $\left(3218 \mathrm{~kg} \cdot \mathrm{ha}^{-1}\right)$ and minimum grain yield was observed $\left(3125 \mathrm{~kg} \cdot \mathrm{ha}^{-1}\right)$ in Hysun-33. The response of $\mathrm{N}$ fertilizer rates on grain yield was significant, increasing with application of more
$\mathrm{N}$ fertilizer. Maximum grain yield $\left(3800 \mathrm{~kg} \cdot \mathrm{ha}^{-1}\right.$ ) was produced in $\mathrm{N}_{4}$ treatment followed by $\mathrm{N}_{5}$ treatment that gave the grain yield of $3775 \mathrm{~kg} \cdot \mathrm{ha}^{-1}$. The minimum grain yield $\left(2290 \mathrm{~kg} \cdot \mathrm{ha}^{-1}\right)$ was observed by the treatment where there was no application of nitrogen fertilizer (Table 2). These results were also in conformity with other findings $[21,23]$. The yield was high due to low temperature during 
Table 2. Effect of nitrogen levels on different yield parameters of sunflower hybrids under agro-climatic conditions Gujranwala-Pakistan.

\begin{tabular}{|c|c|c|c|c|c|c|c|c|c|}
\hline \multirow{2}{*}{ Treatments } & \multicolumn{3}{|c|}{ Grain yield $\left(\mathrm{kg} \cdot \mathrm{ha}^{-1}\right)$} & \multicolumn{3}{|c|}{ Harvest index (\%) } & \multicolumn{3}{|c|}{ Grain oil content (\%) } \\
\hline & 2008 & 2009 & Pooled mean & 2008 & 2009 & Pooled mean & 2008 & 2009 & Pooled mean \\
\hline Hysun-33 & $3170 \mathrm{c}$ & $3081 c$ & $3125 c$ & 26.7 & 24.9 & 25.8 & $41.0 \mathrm{c}$ & $40.3 c$ & $40.7 \mathrm{c}$ \\
\hline Hysun-38 & $3340 \mathrm{a}$ & 3338a & 3389a & 24.0 & 25.0 & 24.5 & $43.2 \mathrm{~b}$ & $42.5 b$ & $42.9 \mathrm{~b}$ \\
\hline Pioneer-64A93 & $3262 b$ & $3174 b$ & $3218 b$ & 27.4 & 25.6 & 26.5 & $43.6 \mathrm{a}$ & 43.9a & $43.7 \mathrm{a}$ \\
\hline LSD (0.05) & 19.3 & 17.3 & 16.4 & NS & NS & NS & 0.05 & 0.12 & 0.08 \\
\hline \multicolumn{10}{|l|}{ Nitrogen $\left(\mathrm{kg} \cdot \mathrm{ha}^{-1}\right)$} \\
\hline 0 & 2339d & $2241 \mathrm{e}$ & $2290 \mathrm{e}$ & $20.6 \mathrm{~d}$ & 19.9c & 20.3d & $46.6 \mathrm{a}$ & $45.9 \mathrm{a}$ & $46.2 \mathrm{a}$ \\
\hline 60 & $2961 c$ & $2912 d$ & 2936d & 23.3c & $23.0 \mathrm{~b}$ & 23.1c & $46.5 \mathrm{a}$ & $45.7 \mathrm{a}$ & $46.1 \mathrm{a}$ \\
\hline 120 & $3172 b$ & $3102 c$ & $3137 c$ & $25.4 \mathrm{~b}$ & $23.8 \mathrm{~b}$ & $24.6 b$ & $44.1 \mathrm{~b}$ & $43.5 b$ & $43.8 \mathrm{~b}$ \\
\hline 180 & $3809 a$ & 3791a & $3800 a$ & $27.6 \mathrm{a}$ & $26.4 \mathrm{a}$ & $27.0 \mathrm{a}$ & $41.3 \mathrm{c}$ & $40.8 \mathrm{c}$ & $41.0 \mathrm{c}$ \\
\hline 240 & 3806a & $3743 b$ & $3775 b$ & 27.9a & 27.1a & $27.5 \mathrm{a}$ & $40.4 \mathrm{~d}$ & $40.8 \mathrm{c}$ & $40.6 \mathrm{~d}$ \\
\hline LSD (0.05) & 44.0 & 33.3 & 22.6 & 1.5 & 1.4 & 1.5 & 0.81 & 0.45 & 0.44 \\
\hline Significance & $*$ & * & * & $*$ & $* *$ & $*$ & $*$ & $*$ & $*$ \\
\hline Interaction $(\mathrm{H} \times \mathrm{N})$ & NS & NS & NS & NS & NS & NS & NS & NS & NS \\
\hline
\end{tabular}

Figures in the same column with different letters differ significantly at probability level of *P=5\%, **P=1\%, NS—non-significant.

the grain filling stage and the crop grown under the minimum temperature with high moisture content in not only atmosphere but also under the crop root zone as well in the form of precipitation and these environmental conditions leads to better crop yield.

\subsection{Harvest Index}

The harvest index represents the physiological competence of plants to change the fraction of photoassimilates to grain yield. The data in Table 2, demonstrated that seasonal effect on harvest index (HI) of sunflower hybrids that was non significant. The sunflower hybrid variations with respect to HI were non-significant. Considerably high HI for Pioneer-64A93 might be achieved due to its genotypic dominance to utilize more photoassimilates for grain yield formation. These results also corroborate the studies carried out by other scientists [24, 25].

\subsection{Achene Oil Content}

Pioneer-64A93 produced the maximum grain oil content (GOC) (43.7\%) followed by Hysun-38 (42.9\%), while the minimum GOC (40.7\%) was observed in Hysun-33 sunflower hybrid. The response to $\mathrm{N}$ fertilizer rates decreased with increasing application of $\mathrm{N}$ fertilizer. Maximum GOC (46.2\%) were produced in $\mathrm{N}_{1}$ treatment followed by $\mathrm{N}_{2}(46.1 \%)$. The minimum GOC $(40.6 \%)$ observed in $\mathrm{N}_{5}$. This result shows that an increase in $\mathrm{N}$ fertilizer increases the grain yield but reduces the GOC [26, 27].

\subsection{Nitrogen Utilization Efficiency $\left(\mathrm{kg} \cdot \mathrm{kg}^{-1}\right)$}

The differentiation of nitrogen use efficiency (NUE) in sunflower hybrid was non-significant during both years of experiments. Averaged over all, maximum NUE was $\left(6.2 \mathrm{~kg} \cdot \mathrm{kg}^{-1}\right)$ observed by Hysun-38 followed by Hysun-33 $\left(5.9 \mathrm{~kg} \cdot \mathrm{kg}^{-1}\right)$ and minimum value of NUE (5.7 $\left.\mathrm{kg} \cdot \mathrm{kg}^{-1}\right)$ observed in Pioneer-64A93 sunflower hybrid (data not shown). Furthermore, significant variations were found in NUE in different $\mathrm{N}$ treatments, where increasing rates of $\mathrm{N}$ decreased the NUE over all. Thus, the highest NUE $\left(11.3 \mathrm{~kg} \cdot \mathrm{kg}^{-1}\right)$ were found when when the application was $60 \mathrm{~kg} \cdot \mathrm{N} \mathrm{ha}^{-1}$. The minimum value of mean NUE $\left(0.0 \mathrm{~kg} \cdot \mathrm{kg}^{-1}\right)$ was observed from plots fertilized with $0 \mathrm{~kg} \cdot \mathrm{N} \cdot \mathrm{ha}^{-1}\left(\mathrm{~N}_{1}\right)$. Similar findings were also reported by $[28,29]$.

\section{Conclusion}

From this study we can conclude that Hysun-38 should be planted to obtain higher achene yield and better quality oil contents, since it performed best with excellent characteristics under agro-climatic conditions of $\mathrm{Gu}-$ jranwala compared to Hysun-33 and Pioneer-64A93 hybrids. For maximum economic benefits, application of $180 \mathrm{~kg} \cdot \mathrm{ha}^{-1}$ was better under well irrigated conditions compared to other different $\mathrm{N}$ rates evaluated. Further research may be required in this area (sub humid area) for sunflower crop to identify best agronomic management strategies under agro-climatic conditions of Gujranwala in order to achieve high yield and profitable edible oil production in the sub-humid region of Pakistan. 


\section{Acknowledgements}

The first author is grateful to The University of Agriculture, Faisalabad-Pakistan, for providing partial funding to conduct research project. The author is also appreciative from the staff (Dr. Abid Hussain, Dr. Aftab Wajid, Dr. Tasneem Khaliq, and Dr. Syeda Rifat Sultana) of Agroclimatology laboratory, Department of Agronomy, University of Agriculture, Faisalabad for their help in data collection and analysis of data as well.

\section{REFERENCES}

[1] A. O. Demir, A. T. G. H. Buyukcangaz and Z. M. T. E. S. Koksal, "Deficit Irrigation of Sunflower (Helianthus annuus L.) in a Sub-Humid Climate,” Irrigation Science, Vol. 24, No. 4, pp 279-289. doi:0.1007/s00271-006-0028-X

[2] M. Usman, M. Arshad, A. Ahmad, N. Ahmad, M. Ziaul-Haq, A. Wajid, T. Khaliq, W. Nasim, H. Ali and S. Ahmad, "Lower and Upper Baselines for Crop Water Stress Index and Yield of Gossypium hirsutum L. under Variable Irrigation Regimes in Irrigated Semiarid Envinment,” Pakistan Journal of Botany, Vol. 42, No. 4, 2010, pp. 2541-2550.

[3] R. Ahmad, N. Hussain, T. Mahmood and M. Amjad, "Growth and Yield Performance of Some Sunflower (Helianthus annuus L.) Hybrids Planted in Spring Season,” Pakistan Journal of Agricultural Sciences, Vol. 29, No. 3, 1992, pp. 288-291.

[4] Soil Survey Staff, "Keys to Soil Taxonomy,” 8th Edition, United States Department of Agriculture, National Sources Conservation Service, Washington DC, 1998.

[5] M. M. Zubillaga, J. P. Aristi and R. S. Lavado, "Effect of Phosphorus and Nitrogen Fertilization on Sunflower Nitrogen Uptake and Yield," Journal of Agronomy and Crop Science, Vol. 188, No. 4, 2002, pp. 267-274. doi:046/j.1439-037X.2002.00570.x

[6] S. D. Koutroubas, D. K. Papakosta and A. Doitsinis, "Nitrogen Utilization Efficiency of Safflower Hybrids and Open-Pollinated Varieties under Mediterranean Conditions,” Field Crops Research, Vol. 107, No. 1, 2008, pp. 56-61. doi:016/j.fcr.2007.12.009

[7] GOP (Government of Pakistan), "Economic Survey of Pakistan,” Finance Division Economic Advisory Wing Islamabad Pakistan, 2009, pp. 21-23.

[8] M. A. Malik, M. F. Saleem, M. Sana and A. Rehman, "Suitable Level of N, P and K for Harvesting the Maximum Economic Returns of Sunflower," International Journal of Agriculture and Biology, Vol. 6, No. 2, 2004, pp. 240-242.

[9] W. Nasim, A. Ahmad, A. Wajid, J. Akhtar and D. Muhammad, "Nitrogen Effects on Growth and Development of Sunflower Hybrids under Agro-Climatic Conditions of Multan,” Pakistan Journal of Botany, Vol. 43, No. 4, 2011, pp. 2083-2092.

[10] R. G. D. Steel, J. H. Torrie and D. A. Deekey, "Principles and Procedures of Statistics. A Biometrical Approach,” 3nd Edition, McGraw Hill Book, New York, 1997. pp. 400-428.

[11] W. Nasim, "Modeling the Impact of Climate Change on Nitrogen Use Efficiency in Sunflower (Helianthus annuus L.) under Different Agro-Climatic Conditions of Punjab-Pakistan,” Ph.D. Thesis, University of Agriculture, Faisalabad, 2010.

[12] I. Cechin and T. F. Fumis, "Effect of Nitrogen Supply on Growth and Photosynthesis of Sunflower Plants Grown in the Greenhouse,” Plant Science, Vol. 166, No. 5, 2004, pp. 1379-1385. doi:016/j.plantsci.2004.01.020

[13] M. K. Hussain, E. Rasul and S. K. Ali, "Growth Analysis of Sunflower (Helianthus annuus L.) under Drought Conditions," International Journal of Agriculture and Biology, Vol. 2, No. 1-2, 2000, pp. 136-140.

[14] A. Wajid, A. Ghaffar, M. Maqsood, K. Hussain and W. Nasim, "Yield Response of Maize Hybrids to Varying Nitrogen Rates,” Pakistan Journal of Agricultural Sciences, Vol. 44, No. 2, 2007, pp. 217-220.

[15] M. Ishfaq, A. Ali, A. Khaliq and M. Yaseen, “Allometry, Agronomic Traits and Yield of Autumn Planted Sunflower Hybrids under Varying Row Spacing,” Pakistan Journal of Agricultural Sciences, Vol. 46, No. 4, 2009, pp. 248-257.

[16] M. Usman, M. Arshad, A. Ahmad, N. Ahmad, M. Ziaul-Haq, A. Wajid, T. Khaliq, W. Nasim, H. Ali and S. Ahmad, "Lower and Upper Baselines for Crop Water Stress Index and Yield of Gossypium hirsutum L. under Variable Irrigation Regimes in Irrigated Semiarid Environment," Pakistan Journal of Botany, Vol. 42, No. 4, 2010, pp. 2541-2550.

[17] M. A. Munir, M. A. Malik and M. F. Saleem, "Impact of Integration of Crop Manuring and Nitrogen Application on Growth, Yield and Quality of Spring Planted Sunflower (Helianthus annuus L.)," Pakistan Journal of Botany, Vol. 39, No. 2, 2007, pp. 441-449.

[18] J. Iqbal, B. Hussain, M. F. Saleem, M. A. Munir and M. Aslam, "bBio-Economics of Autumn Planted Sunflower (Helianthus annuus L.) Hybrids under Different NPK Applications," Pakistan Journal of Agricultural Sciences, Vol. 45, No. 3, 2008, pp. 19-24.

[19] A. Wajid, A. Ahmad, T. Khaliq, S. Alam, A. Hussain, K. Hussain, W. Nasim, M. Usman and S. Ahmad, "Quantification of Growth, Yield and Radiation Use Efficiency of Promising Cotton Cultivars at Varying Nitrogen Levels," Pakistan Journal of Botany, Vol. 42, No. 3, 2010, pp. 1703-1711.

[20] A. Khaliq and Z. A. Cheema, "Influence of Irrigation and Nitrogen Management on Some Agronomic Traits and Yield of Hybrid Sunflower," International Journal of Agriculture and Biology, Vol. 7, No. 6, 2005, pp. 915-919.

[21] A. Ahmad, S. Iqbal, S. Ahmad, T. Khaliq, W. Nasim, A. Hussain, M. Zia-ul-Haq and G. Hoogenboom, "Seasonal Growth, Radiation Interception, Its Conversion Efficiency and Aerial Dry Biomass Production of Oryza sativa L. under Diverse Agro-Environments in Pakistan,” Pakistan Journal of Botany, Vol. 41, No. 3, 2009, pp. 1241-1257. 
[22] A. Anwar-ul-Haq, A. Rashid, M. A. Butt, M. A. Akhter, M. Aslam and A. Saeed, "Evaluation of Sunflower ( $\mathrm{He}-$ lianthus annuus L.) Hybrids for Yield and Yield Components in Central Punjab," Journal of Agricultural Research, Vol. 44, No. 4, 2006, pp. 277-285.

[23] H. Ozer, T. Polat and E. Ozturk, "Response of Irrigated Sunflower Hybrids to Nitrogen Fertilization, Growth, Yield and Yield Components,” Plant, Soil and Environment, Vol. 50, 2004, pp. 205-211.

[24] E. Gholinezhad, A. Aynaband, A. H. Ghorthapeh, G. Noormohamadi and I. Bernousi, "Study of the Effect of Drought Stress on Yield, Yield Components and Harvest Index of Sunflower Hybrid Iroflor at Different Levels of Nitrogen and Plant Population," Notulae Botanicae Horti Agrobotanici Cluj-Napoca, Vol. 37, No. 2, 2009, pp. 8594.

[25] V. D. Zheljazkov, B. A. Vick, B. S. Baldwin, N. Buehring, T. Astatkie and B. Johnson, "Oil Content and Saturated Fatty Acids in Sunflower as a Function of Planting Date, Nitrogen Rate, and Hybrid,” Agronomy Journal, Vol. 101, No. 4, 2009, pp. 1003-1011. doi:134/agronj2009.0011

[26] M. A. Malik, S. H. Shah, S. Mahmood and M. A. Cheema, "Effect of Various Planting Geometries on the Growth, Seed Yield and Oil Contents of New Sunflower Hybrid (SF-187)," International Journal of Agriculture and Biology, Vol. 3, No. 1, 2001, pp. 55-56.

[27] W. Nasim, A. Ahmad, H. M. Hammad, H. J. Chaudhary and M. F. H. Munis, "Effect of Nitrogen on Growth and Yield of Sunflower under Semiarid Conditions of Pakistan,” Pakistan Journal of Botany, 2012 in press.

[28] S. D. Koutroubas, D. K. Papakosta and A. Doitsinis, "Nitrogen Utilization Efficiency of Safflower Hybrids and Open-Pollinated Varieties under Mediterranean Conditions,” Field Crops Res. Vol. 107, No. 1, 2008, pp. 56-61. doi:016/j.fcr.2007.12.009

[29] F. Montemurro and D. D. Giorgio, "Quality and Nitrogen Use Efficiency of Sunflower Grown at Different Nitrogen Levels under Mediterranean Conditions,” Journal of Plant Nutrition, Vol. 28, No. 2, 2005, pp. 335-350. doi:081/PLN-200047627 